\title{
Knowledge Economy and Turkey In Terms Of Innovation and Education
}

\author{
Ph. D. Candidate Burcu Sakız (Istanbul Aydın University, Turkey) \\ Semih Sakız (Garanti Technology, Turkey)
}

\begin{abstract}
Communication and information technologies have started to emerge since the 40s resulting major changes in the way business has been conducted and effected global economy. Transitions to knowledge-intensive business models become popular since late 1950s. Additionally intellectual capabilities become more important than physical inputs. Having sufficient national production and technology to create a welfare society similar to developed countries is crucial for any modern nation. One of the main developmental leverages for the globalization becomes the knowledge based economic approach. Developed by World Bank "Knowledge Assessment Methodology" is very important methodology in order to measure the progress of countries towards having a knowledge based economy. World Bank's four Knowledge Economy pillars: economic and institutional regime, education, innovation, and Information and Communication Technologies (ICTs) developed for countries to make basic assessment of countries' readiness for the knowledge economy and help them the transition to a Knowledge Economy. In this study, knowledge economy concept and its properties are presented. Furthermore this paper introduces the analysis of knowledge economy from Turkey's perspective especially for the role of innovation and education pillars in the development of Turkey.
\end{abstract}

\section{Introduction}

According to Alvin Toffler, one of the most important management scholars of our age, history should be held in three segments and by his saying these segments should be called as waves. These waves are first wave: Agricultural Society; second wave: Industrial Society; third wave: Knowledge Society (Toffler, 1984). Since the first stage of history, agriculture has been in satisfying human needs and societies that could be able to use it most effectively have created a power field over other societies. Then comes industrial revolution. Mechanization has been the mainstay of Industrial Society. In the knowledge society that we are in service/knowledge technologies have come into prominence. Weight of input from natural sources and physical capital to industry will go towards qualitative human beings in the first period of information in the later periods. A requirement for computers triggered a new wave which can do calculations needed by simulations within the context of The Manhattan Project which was started with the aim of making atomic bomb in The United States of America during The Second World War. It can be said that knowledge age has started with the improvement of first programmable computer ENIAC in 1945. Use of computer in academic and business world and in personal life has increased over time, major changes have been observed in social and economic structure. Knowledge Society has witnessed to alteration and transformation of societies. Knowledge brings speed and effectiveness. Therefore, it plays the key role for the economy. Relations of production and business connections have been transforming, the resulting velocity, provided efficiency support each other with technological improvements.

Today's global competitive environment, becoming successful and increasing the productivity will be possible not only by structure-process and technological changes but also and the most important by teaching and developing of high quality human sources and by preparing them for the future. To measure how intense countries use their knowledge and communication technologies and contributions do these technologies provide has become a must to be able to make a comparative analysis. In this process which can be named as modernization of economic and social life, Turkey has been reconstructing certain things in order to keep pace with alterations and to be competitive benefiting from advantages of the process (Çirasun, 2011). These improvements and evaluating these improvements by measuring them are crucial to compare Turkey to other countries in the world with regards to Turkey's progress.

\section{Literature Review}

The first study we focused on is Gür's (2001) study about constructing a new framework which is to be utilized for the assessment of possible strategies which can be applied during the transition to a knowledge-based economy. He developed mixed integer programming model in order to determine the required levels of human resources and information and communications technology investments for given levels of R\&D investment of the country that determines most significant characteristic of the phenomenon. The results indicate that Turkish government should increase R\&D to considerable levels in order to trigger the transition to a knowledge-based economy. Second important finding is transformation towards a knowledge-based economy with an inefficient innovation system may require considerable amounts of additional resources compared to transforming with a more efficient system. 
Salduz (2005) studied that Turkey's position as a candidate country in adaptation to the Lisbon Strategy. She gives general information concerning knowledge economy and EU's activities aiming to reach Lisbon strategy and EU-Turkey comparison with using knowledge economy indicators. Also she examined Turkey's EU (European Union) adaptation process. Study reveals that Turkish economy has many disadvantages both for knowledge production and using information technologies and economy needs reconstruction to close this gap. Furthermore for knowledge economy that reconstruction requires renovations in science and technology policies, education policy and industrial policy needs reconstruction, too.

Özcan (2007) studied organizations in Turkey in terms of their extent to be knowledge-based by making a comparative analysis between Turkey and UK. Top 500 organizations in terms of owning most total assets to the parameters of knowledge economy in London and Istanbul are compared. The results indicate that organizations in Turkey has capability to compete with organization in top knowledge economies in terms of awareness on strategic importance of knowledge, but in terms of innovation organizations in Turkey are behind organizations in the UK.

Düzgün (2008) studied the shift of employment towards knowledge intensive industries, knowledge occupations and ICT utilization in Turkey. Results show that although there is an increase in knowledge and services employment, manufacturing employment also continues to grow in Turkey and middle knowledge intensity sectors shows the largest employment growth over the analyzed period. Also according to the ranking of Turkey in basic ICT indexes despite the increase in utilization of main ICTs, Turkey is still behind usage level in developed countries.

Kaynak (2008) studied that the meaning of knowledge economy and the economic effects of knowledge economy for Turkey. He used World Bank's Knowledge Assessment Methodology and used in analysis of knowledge economy performances of the countries. To accomplish this, he analyzed Basic Scorecard, the Knowledge Economy Index and Custom Scorecards for Turkey with 83 parameters. The results indicates that Turkey had a moderate performance according to the Basic Scorecard.

Arıkan (2008) examined the dynamics of the innovation construct in Turkey with 122 firms from a wide variety of sectors, through exploring the characteristics of organizations in terms of their openness to innovations. The results show that innovation leads to better business performance. An organization's market orientation, learning orientation, and entrepreneurial orientation lead to more openness to innovations.

Kaynak (2011) studied Turkey's science and technology situation and did a benchmark with EU. Result of his work stated that EU-27 member countries perform better than Turkey in terms of the variables as R\&D expenditures, patents adopted by United States Trademark Office (USPTO), total researchers working at R\&D, advanced technology patents, exports of advanced technology products, patent applications to European Patent Office (EPO), human resources in science and technology, doctorate students at science and technology, but Turkey perform better only in terms of woman researcher rate.

Memişoglu (2012) studied major determinants of knowledge based economy that are based on World Bank Knowledge Assessment Framework, on economic performance indicators such as GDP, GDP per capita and economic growth rate in Brazil, Russia, China, India, South Africa and Turkey (BRICST) between years 20002010 by using Panel Data Model. In the BRICST countries ICT infrastructure and secondary education are found to be important infrastructure channels that affect GDP per capita positively. Also it is indicated that R\&D personnel number as an indicator for innovation potential has positive influence on the GDP. Additionally country's ability to innovate, benefit from ICT and enhance economic performance can be affected by accumulation of educated people in R\&D. The major factors that affect economic performance in the BRICST countries found as ICT infrastructure expansion together with educated R\&D personnel.

Işık (2012) studied effects of R\&D, Innovation, Patent, Information Technologies for Turkey in years between 1990-2010. The competitive advantage factors in knowledge economies are analyzed by various methods. As a result of theoretical and empirical analyses, it is determined that the factors of competitive advantage in knowledge economies, contribute to the economic growth and the development of our country's position in the world in respect to knowledge economy.

Özmusul (2013) studied school policies and practices and also their effects on the learning outcomes (reading scores) at upper secondary schools in Turkey according to the PISA test results for year 2009. This research was performed as a descriptive study and examined 150 school principals and 4859 students at upper secondary schools. One of the result of this study is when students are admitted to the school; the high Socio-Economic Degree (SED) schools consider more the student's academic achievement and preference given to family members of current or former students than middle and low SED schools do.

\section{Economy based on Knowledge}

In the past for industrial society physical capital was important. But for knowledge society; information is important besides productivity and innovation are the most basic factors of growth. The current conditions of the 
information society have created the knowledge economy. In knowledge economy, capacity of producing, using, managing knowledge has become the major determinant of productivity and competitiveness. Knowledge economy is a global economy and it is a web economy. It is emerged because of intensive knowledge in economic activities, improvements in information and communication technologies, and globalization of economic activities. Organisation for Economic Cooperation and Development (OECD) defines knowledge economy as "Economy in which knowledge is being used in production and distribution." (OECD, 1996).

One of the most frequent features of knowledge based economies is that firms tend to produce as firm assemblages not by themselves. Many small and medium sized companies are clustering and are in joint production under the management of a large company. In the long term economies of scales are replaced with economies of scope. The second feature is tendency of using less energy in production. As increasing returns strengthen in the short term, firm assemblages increase the tendency of emerging field economies and increasing returns. In addition, a small number of experts working in coordination with each other and qualified manpower utilization lead to increased productivity by strengthening the effectiveness of labor on fixed facilities. Besides, emerging technologies and changes in the production structure have changed the demand structure significantly (Acar, 2000). Information society will be the society of increasing efficiency, increasing returns and field economies.

Features of knowledge economy have been determined by Don Tapscott (1998) as follows: Knowledge is the basic production factor, Knowledge economy is a digital economy, Virtualization plays an important role in the knowledge economy. Developments in information and communication technologies affect all economic units. The economic structure becomes very dynamic, complex and difficult to predict. Production, consumption, distribution relationships and market structure which are described as the three main elements of the economy are being restructured based on knowledge. From the perspective of the consumer, the consumers may take goods and services more quickly, without being limited by time and space; consumer behavior can be analyzed better in digital environments. Economy is guided by consumers. Barriers to market entry and exit reduce and information becomes a function of competition (Kara, 2005). Only innovative and entrepreneur, knowledge based corporations which can adapt market place quickly, manage change, take part not only in local market but global market can be successful. Because borders have removed, producing innovative products and services that can compete with global firms have become an obligation. The economic effects of physical distance and the cost of access to information are reduced through information and communication technologies. Thus, new business start-up costs are decreasing and the chance to compete in new markets is rising. While in industry based economies success of firms is measured by "profit" physically, now "market value" has become the measure. While financial capital is seen as a formerly scarce resource, now qualified human resources become scarce resources (Taşç1, 2007). An increase is observed in labor demand that can be defined as knowledge workers. Besides, it also creates collaboration opportunities for information and communication technologies to conceive high qualified products with low costs (European Commission, 2001). It is possible to say that the economic model in which knowledge comes into prominence, forces existing business processes and professions to be more qualified (Meçik, 2013). Especially in the second term of the 20th century by the increase in technological researches and in the usage of the technical tools and equipments, there had been a knowledge explosion because of new inventions.

\section{Four Pillars of Knowledge Economy}

Knowledge itself is difficult component to quantify and calculate its market value. The reason is knowledge has no fixed capacity, shows more rapid change in that sense and tends to be obsolete in a short period of time. The first attempt for the development of a framework in order to interpret of data relating to science, technology and innovation has been made by OECD. OECD has prepared manuals for measuring knowledge inputs mostly emphasis on input measures of R\&D expenditures and human resources and aimed at informing policy makers about the scope and limitations of innovation activities and allow countries to conduct international comparisons on knowledge based economy.

\begin{tabular}{|l|l|}
\hline Knowledge Economy Indicators & Manuals \\
\hline R\&D expenditures & Frascati Manual (1993) \\
\hline Technology balance of payments & TBP Manual 1990 \\
\hline Innovation & Oslo Manual 1992 (revised in 2005) \\
\hline Patent & Patent Manual 1994 \\
\hline Human Resources & Canberra Manual 1995 \\
\hline
\end{tabular}

Table 1. List of OECD Manuals Source: OECD, 1996

Along with OECD, many other institutions such as UNESCO, World Bank, ITU (International Telecommunication Union), Eurostat and United Nations have introduced a range of indicators are widely use to analyze country's potential for knowledge-based economy. Decision makers should evaluate their situation in terms of information and communication of their countries when determining the target for knowledge economy 
and knowledge society. They build several indexes in this regard. Such sample institutions which develop these indexes are McConnell International (MI) a global technology policy and management consulting firm, Harvard University International Development Center, The Economist Intelligent Unit, The United Nations Conference on Trade and Development (UNCTAD), The United Nations Development Program (with its Technology Achievement Index), World Economic Forum, The Mosaic Group and The World Bank (Beig, et.al, 2007).

Education, economic incentives and institutional regime, innovation, information and communication technologies are held as main pillars of knowledge economy by World Bank (World Bank, 2010). Knowledge Assessment Methodology-KAM is a method built by WB that aims to provide identifying problems and opportunities countries may face towards transition to knowledge economy. World Bank Institute started program in 1999. KAM has 69 structural/qualitative variables to benchmark performance on 4 pillars and variables normalized from 0 (worst) to 10 (best) for 100 countries. The unique strength of the KAM lies in its cross-sectoral approach that allows a holistic view of the wide spectrum of factors relevant to the knowledge economy. These pillars are briefly summed up as follows:

\begin{tabular}{|l|l|}
\hline Pillars & Indicators \\
\hline Economic and institutional regime & $\begin{array}{l}\text { - Tariff and non-tariff barriers } \\
\text { - Regulatory quality } \\
\text { - Rule of law }\end{array}$ \\
\hline Education and skill of population & $\begin{array}{l}\text { - Adult literacy rate } \\
\text { - Gross secondary enrollment rate } \\
\text { - Gross tertiary enrollment rate }\end{array}$ \\
\hline Information infrastructure & $\begin{array}{l}\text { - Telephones per } 1,000 \text { people } \\
\text { - Computers per } 1,000 \text { people }\end{array}$ \\
\hline & - Internet users per 1.000 people \\
\hline Innovation system & $\begin{array}{l}\text { - Royalty payments and receipts, US\$ per person } \\
\text { - Technical journal articles per million people }\end{array}$ \\
\hline
\end{tabular}

Table 2. Pillars of Knowledge Economy. Source: WorldBank

Knowledge Economy Index is used to produce economic performance and to possibility of making comparisons through knowledge based indicators. Performance of the knowledge economy is measured by using the basic score card, the knowledge economy index and specific score card models of knowledge assessment methodology. Basic score card determines the performance by using four basic factors of knowledge economy. Knowledge Economy Index shows a country's or a region's overall level of development in the knowledge economy. Specific score card is used while making a more flexible comparison.

\section{Knowledge Economy and Turkey}

According to the Turkey Prime Ministry Investment Support and Promotion Agency, Turkey is aware that role of information and communication technologies will be more important in the future compared to present. This development and search for solutions that appropriate for age's requirements which growth brought along and today's economic and social life's access to the most current and fast solutions as soon as possible underlie the information and communication technologies. In this respect, Turkey has increased the interest in information and communication technologies in recent years and has started working to have a voice in this sector. The most obvious ones in this study are new incentives for investors and R\&D Law. Predictions for future are as follows:

- As the young population and the online market grow, the number of mobile phone subscribers is expected to reach 75 million by 2017 .

- In Turkey, expenditures for hardware, software, information and communication services and telecommunication services are expected to rise to $\$ 25$ billion by 2016 .

- In Turkey, expenditures for information and communication technologies are expected to grow faster than average of the world. When potential and large domestic market is taken into account, sector is expected to grow with a 7\% compound rate of growth during 2012-2017.

- Computers with internet access are available in more than half of the households in Turkey; this rate is expected to rise by $65.6 \%$ in next five years.

- $\quad$ Rate of Internet users in Turkey is about 42\%; this rate is expected to rise over 47\% in 2017.

In accordance with Turkey's challenging vision for 2023 when Turkish Republic's 100th year will be celebrated, information and communication sector is expected on higher goals. These goals includes as follows:

- Increasing the number of broadband subscribers to 30 million.

- $\quad$ Providing 14 million households Internet connection at $1000 \mathrm{Mbps}$. 
- Increasing the share of sector in GDP from $2.9 \%$ to $8 \%$.

- Becoming one of ten biggest countries in e-transformation.

- To have $80 \%$ of population gained ability of computer using.

- Increasing the number of companies which operates in Technology Development Zones to 5500; increasing the number of employers to 65000 ; increasing the export to $\$ 10$ million.

- To make size of Information and communication technologies sector reach $\$ 160$ billion with a market growth by about $15 \%$ every year.

- Increasing the share of R\&D expenditures in GDP from $0.85 \%$ to 3\% (Turkey Prime Ministry Investment Support and Promotion Agency, 2014).

We can see that Toffler's first, second and third waves are all available at same time for Turkey. Turkey could be a young industrial country by the courtesy of policies such as protectionism and incentives. Turkey owes partial change to the law of diminishing returns. Law of diminishing returns, gives developing countries a chance to learn producing goods with high added value. However, law of increasing returns is valid in knowledge society. Thus, specialization in the production of goods with high added value and making production more efficient through knowledge are required (Acar, 2000). In this regard, according to the "Information and Communication Technologies toward 2023 Goals" report of International Investors Association, it is expected that impact of 1 unit of growth in information and communication sector will be 1.8 units of growth in whole economy. In 2011, information and communication sector size at the global level has reached \$4.1 trillion. And the size of the sector in Turkey is estimated to be $\$ 30,3$ billion. Although share of our country whose economy is the 17 th economy of the world as economical size, is about $1 \%$, country's share in global information and communication sector remaining at $0.75 \%$ indicates the sector's growth potential. When the sub-sectors of the market in Turkey are analyzed, it is seen that the growth potential of the information technologies industry whose share is $0.4 \%$ in global market, is much higher. In case of reaching targeted $8 \%$ share of Information and Communication Technologies in \$2 billions GDP, merely to be provided contribution through total factor productivity growth is estimated to be over $\$ 71$ billion (YASED International Investors Association, 2014).

Economical development and knowledge are highly related to each other. The relationship between the Knowledge Economy Index (KEI) and per capita GDP is positive. According to our regression test in the figure below, the relationship between KEI and economical performance is about $85 \%$.

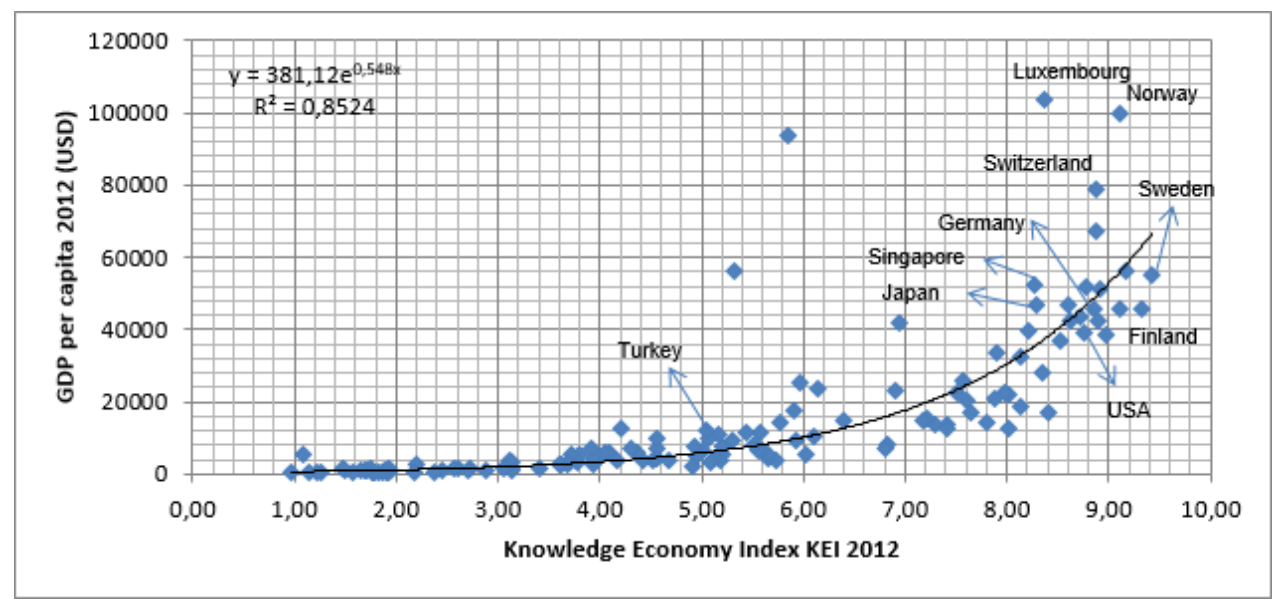

Figure 1. GDP per Capita \& KEI relation. Source: World Bank, 2014.

\subsection{Turkey and World Knowledge Economy Benchmarks}

The underlying reasons behind differences in countries' long-term growth performances are grouped under four main headings such as investment (fixed capital, and information and communication technology sector), non-formal education, innovation and structural change. When we consider Turkey according to these headings, it is observed that: Both fixed capital investment and the information and communication sector investments are not sufficient; R\&D expenditures remained behind the fast developing countries but increase in production efficiency by innovating could be achieved; It couldn't be achieved yet to develop the educational level of human capital, Tendency to high-tech products in the structure of production remained limited and structure of production based on low-technology continues. Knowledge Economy Index of Turkey pillars graphic and KEI table are given below. 


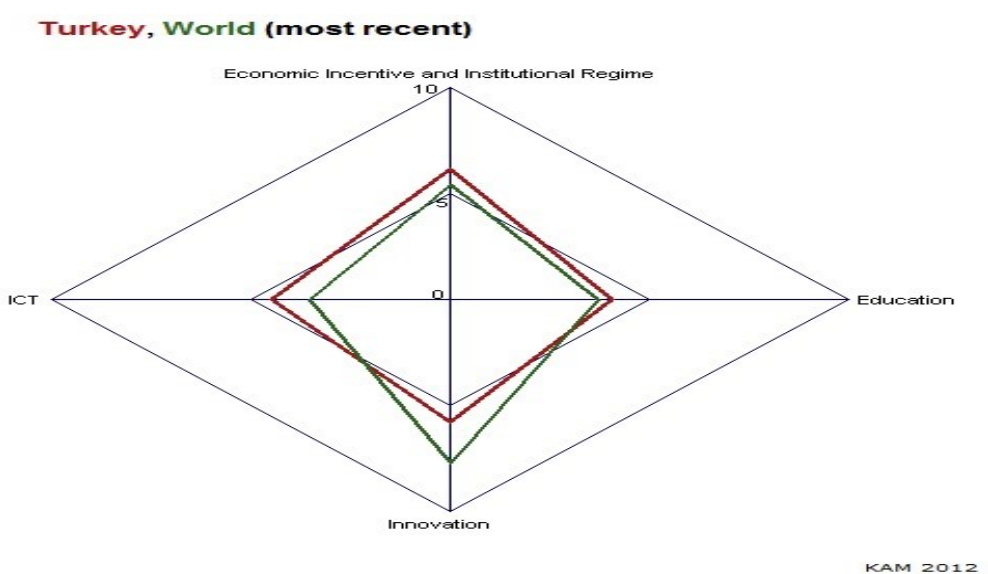

Figure 2. Turkey and World KEI graph Source: World Bank, 2014.

\begin{tabular}{|l|c|c|}
\hline Index & Turkey & World \\
\hline KEI & 5,16 & 5,12 \\
\hline KI & 4,81 & 5,01 \\
\hline Economic Incentives and Institutional Regime & 6,19 & 5,45 \\
\hline Education & 4,11 & 3,72 \\
\hline Innovation & 5,83 & 7,72 \\
\hline ICT & 4,5 & 3,58 \\
\hline
\end{tabular}

Table 3. Turkey and World knowledge indexes Source: World Bank, 2014.

\subsection{Innovation and Education Pillars}

Knowledge has always been important for development. We are in the midst of "knowledge revolution" which significantly increased importance of education, innovations and also updated skills for sustainable economic performance and improvement. An educated and skilled population that can create and use knowledge and an effective innovation system consisting of research centers, universities, think tanks, and other organizations that can create knowledge are two drivers for development. Educated, creative and skilled people and effective national innovation system are two important factors. For innovation system, KAM uses three variables: R\&D per million population, patent applications granted by the US Patent and Trademark Office (USPTO) per million population, and scientific and technical journal articles per million population. In summary KAM's innovation pillar aims to measure country's innovation system-firms, research centers, universities, think tanks, consultants, and other organizations - must be capable of tapping the growing stock of global knowledge, assimilating and adapting it to local needs, and creating new technology.

According to Innovation Union Score Board which is used to measure innovativeness by Europe Union Commission and is compiled through 25 indicators, even Turkey displays an increasing performance since 2006; she is still between countries that categorized as low in terms of innovation. In below figure, rankings of Turkey and other countries can be seen. Also we get application data from European Patent Office to compare European countries with Turkey. Turkey still has a lot of potential to grow its performance compared to its population. Moreover according to Turkish Patent Institute's data, Turkey's patent application numbers are increasing since 20 years.

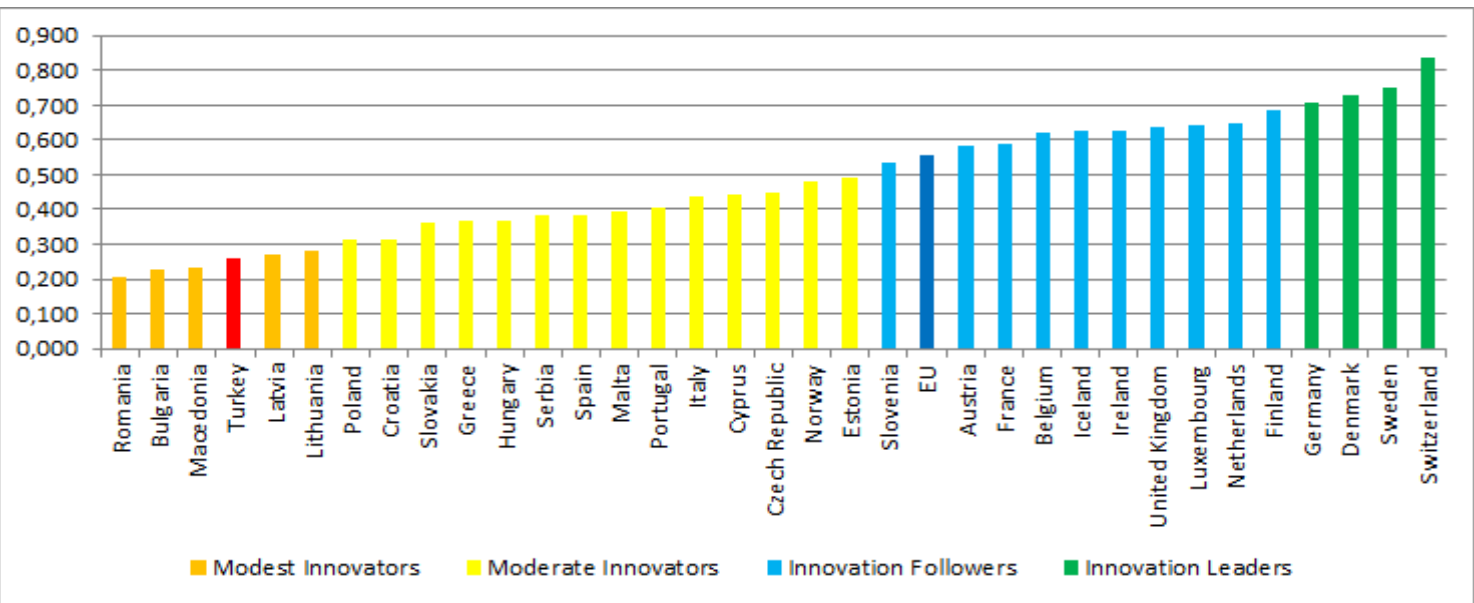

Figure 3. Innovation Union Scoreboard 2015 Source: European Commission, 2015. 


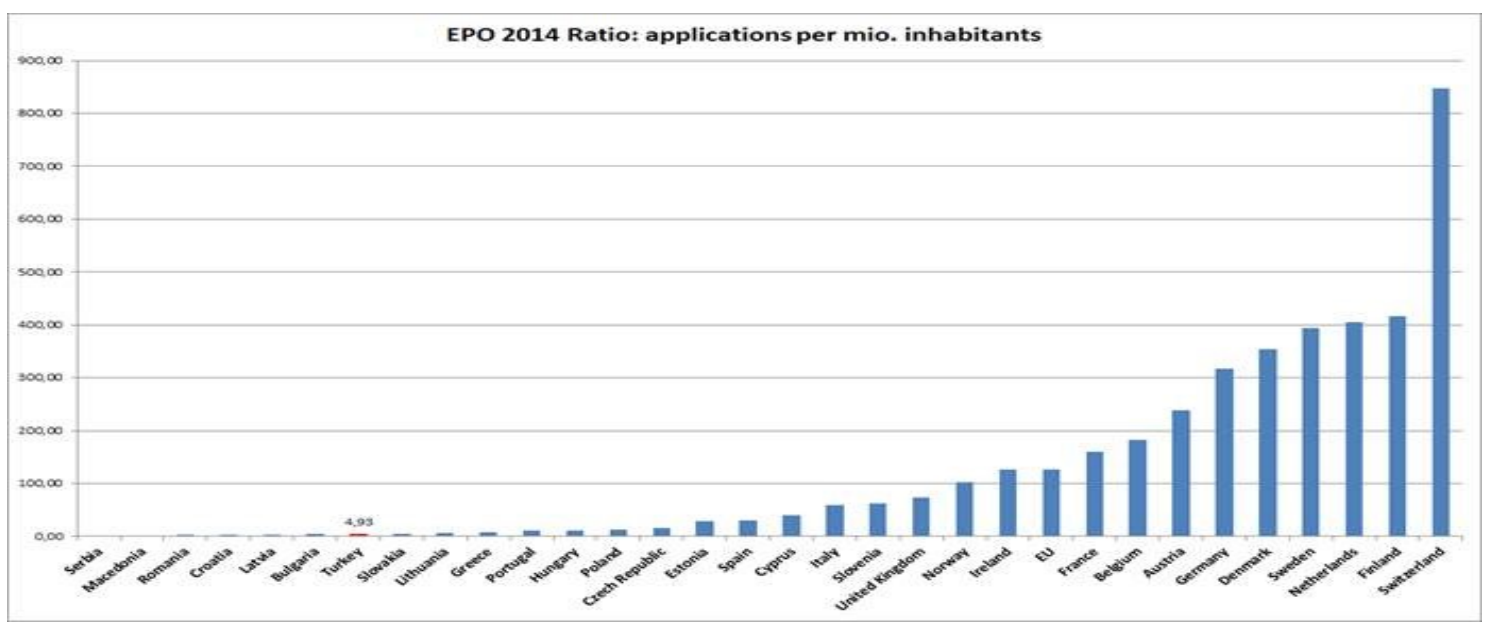

Figure 4. European Patent Office applications per mio. inhabitants Source: EPO, 2015.

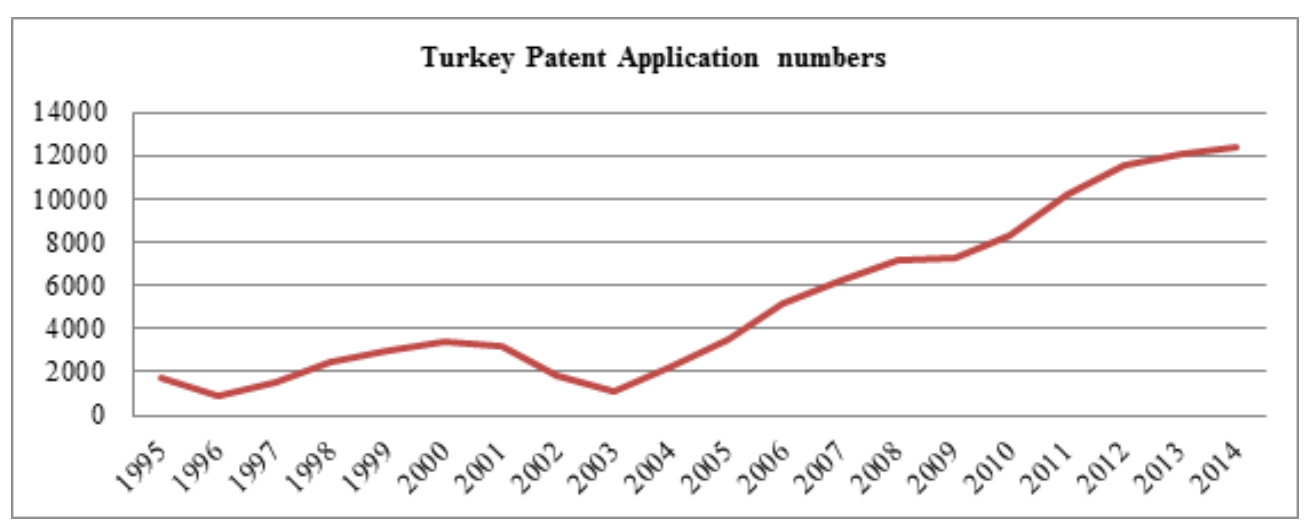

Figure 5. Turkey's Patent Application numbers Source: TPE, 2015

The knowledge economy is transforming the demands of the labor market in economies throughout the world. In industrial countries, where knowledge based industries are expanding rapidly, labor market demands are changing accordingly (World Bank, 2003: 1).World Bank's KAM methodology "education and skills" pillar aims to measure country's people needs education and skills that enables them to create and share, and to use it well. Education has a significant role to play that goes beyond input/ investment models to a finessed output set of specifications. For education pillar, three variables are used: the adult literacy rate (percentage of population aged 15 and above) gives a very broad stock measure of educated population, gross secondary enrollment rate and gross tertiary enrollment rates provide a flow rate. Experiences of developed countries shows that national innovation system, human development, effective education system and information-delivery technologies and business environments should affect each other satisfyingly and they should develop parallel to each other in order to have a successful knowledge economy (World Bank, 2004). Literacy rate, adult total (\% of people ages 15 and above) in Turkey was 94.92 as of 2012 and 95, 5 for 2015 as an estimation. Also Turkey's secondary and tertiary school enrollment percentages since 2010 has an increasing trend.

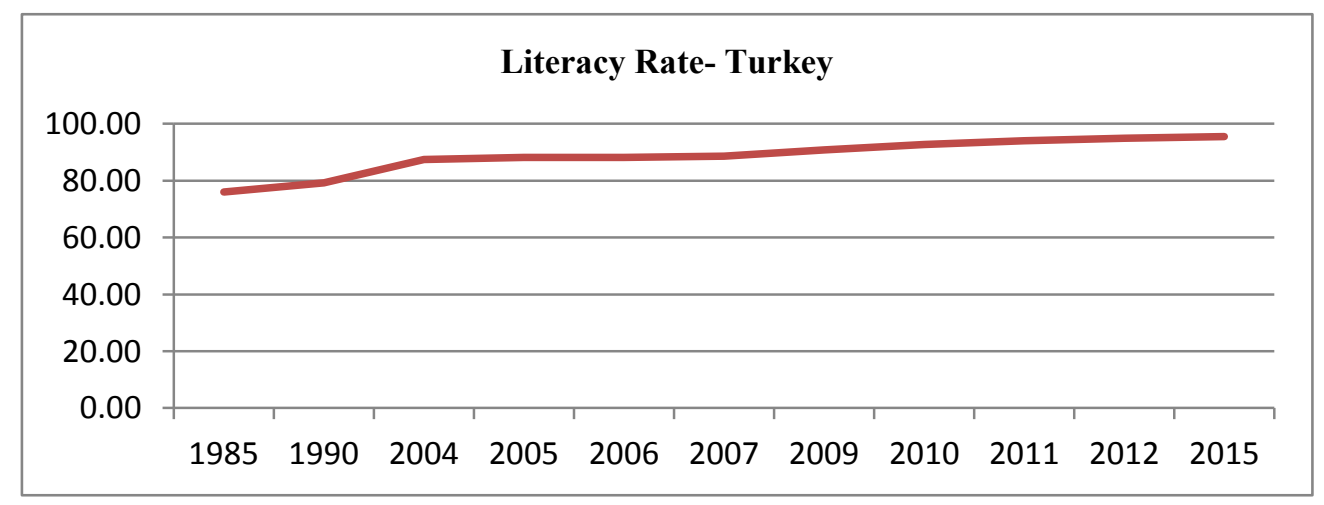

Figure 6. Turkey's Adult literacy rate for last 30 years Source: Unesco, 2015 (year 2015 is * UIS estimation) 


\begin{tabular}{|c|c|c|}
\hline Year & $\begin{array}{c}\text { School enrollment, } \\
\text { secondary (\% net) }\end{array}$ & $\begin{array}{c}\text { School enrollment, } \\
\text { tertiary (\% gross) }\end{array}$ \\
\hline 2010 & 81 & 56 \\
\hline 2011 & 85 & 61 \\
\hline 2012 & 82 & 69 \\
\hline 2013 & 88 & 79 \\
\hline
\end{tabular}

Table 4. Turkey's secondary school enrollment \% Source: World Bank, 2015.

According to OECD, the ongoing economic crisis has only increased the urgency of investing in the acquisition and development of citizens' skills - both through the education system and in the workplace. Investing in structural reforms to boost productivity, such as education and skills development, is key to future growth. Success is no longer measured against national standards alone, but against the best-performing and most rapidly improving education systems in a global economy. Over the past decade, the OECD Programme for International Student Assessment, PISA, has become the world's premier yardstick for evaluating the quality, equity and efficiency of school systems. PISA evaluates education systems worldwide by testing in key subjects' critical thinking in math, science, and reading to 15 year olds (OECD, 2012). It conducts research on the 65 countries that make up 90 percent of the world's economies. The OECD Directorate for Education has found that student achievement in math and science are a sound indicator for future economic health. Namely, nations or cities with good schools can expect a healthy economy (Asia Society, 2015). Turkey has involved this test since 2003. As of 2015, they revealed 2012 PISA test results. According to PISA 2012 results, Turkey is ranked 42nd for math, 41st for reading skills and 45th for science skills. Turkey had low PISA scores in 2003 and recorded an average four-point improvement in all three skills in 2012.
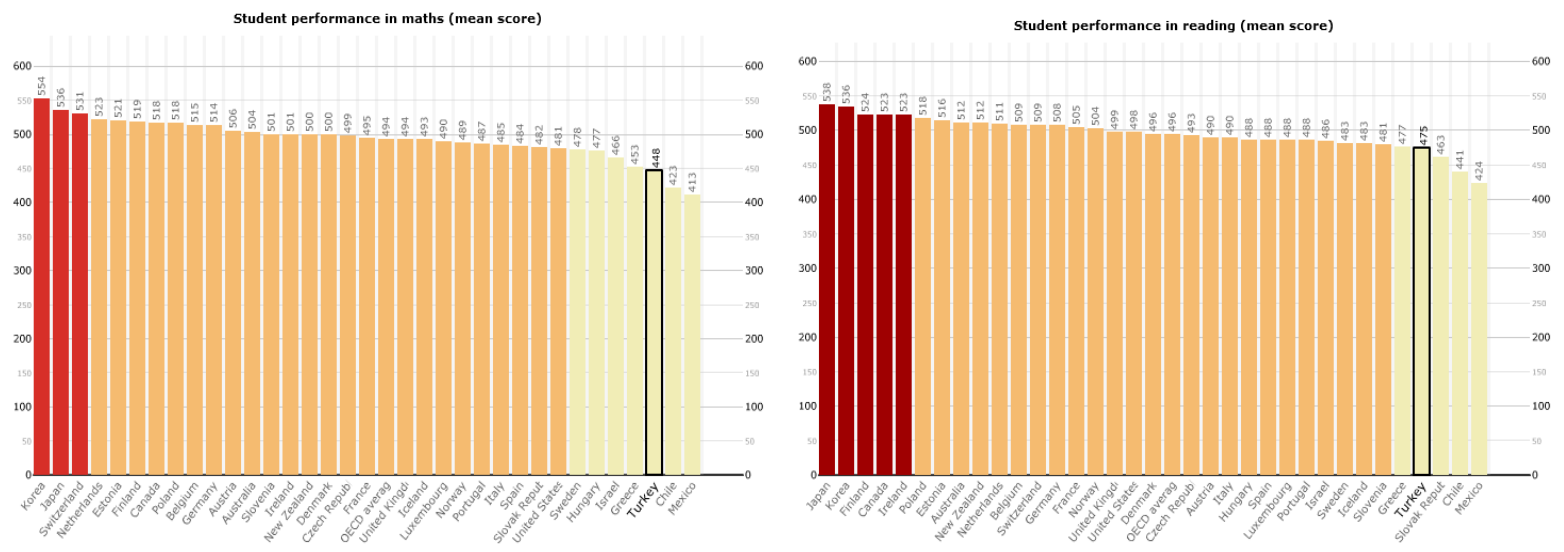

Figure 7. Figure 8. Student performance in math and reading means by countries Source: OECD, 2015

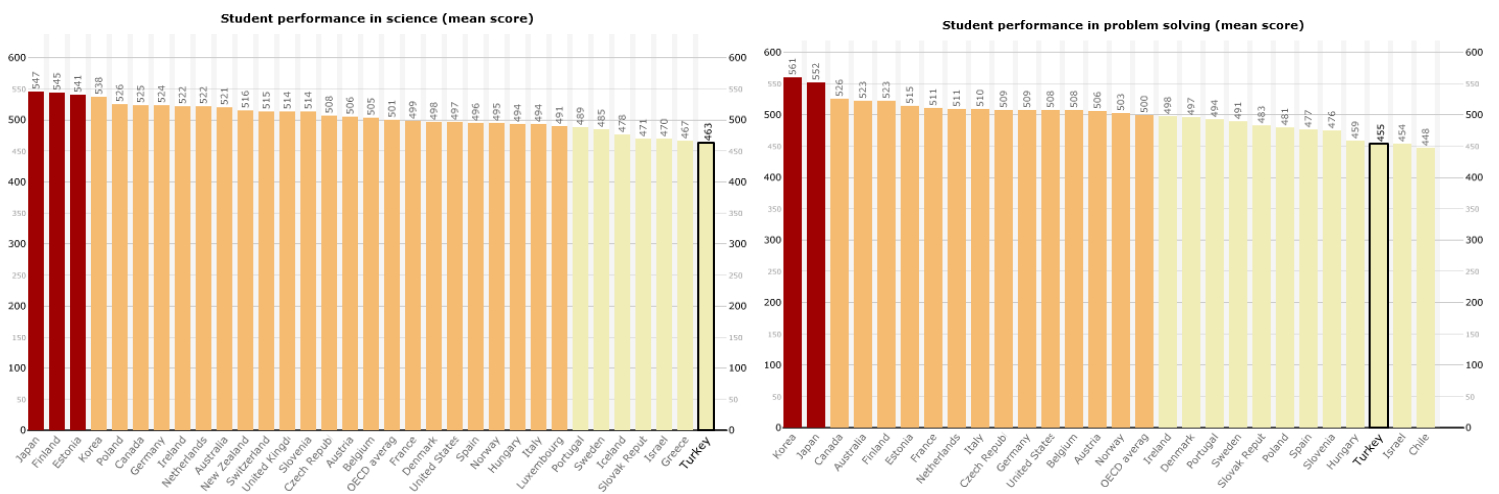

Figure 9. Figure 10. Student performance in science and problem solving means by countries Source: OECD, 2015 


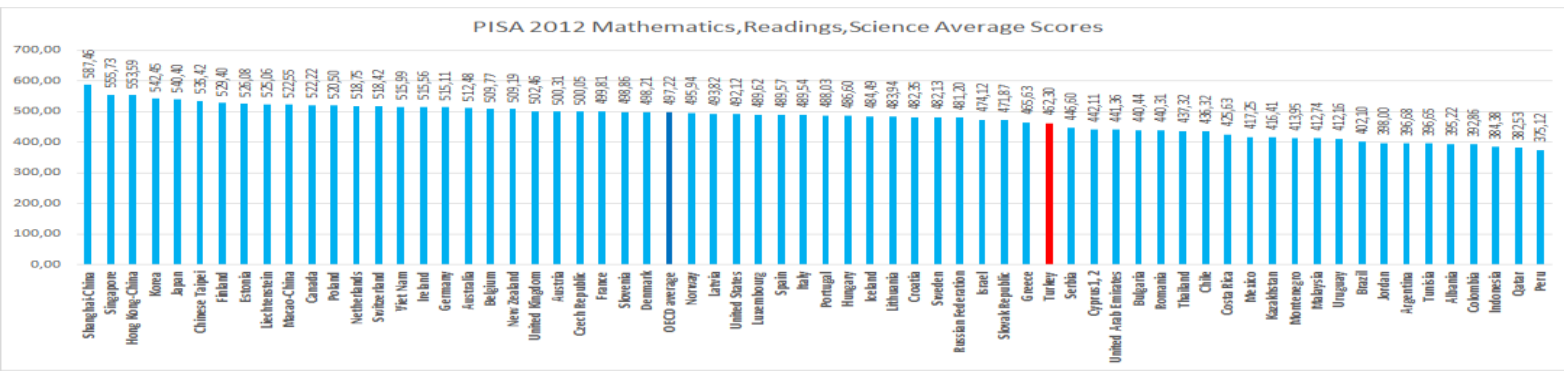

Figure 11. PISA 2012 math, reading, science average scores Source: OECD, 2015

\section{Conclusion}

As we see, knowledge economy relies primarily on the use of ideas rather than physical abilities and on the application of technology rather than the transformation of raw materials or the exploitation of cheap labor. It is an economy in which knowledge is created, acquired, transmitted and used more effectively by organizations, individuals, enterprises, and communities and that's why it promotes economic and social development. We can assume that knowledge-producing institutions are the most important institutions in knowledge era society which is considered as the era the humanity is in. And these institutions are universities and research related institutions. In recent years the growing number of universities In Turkey, can be regarded as one of the signs of being an information society. In his book "Rethinking the Future", Toffler says, "The illiterate of the 21 st century will not be those who cannot read and write, but those who cannot learn, unlearn, and relearn". From this perspective, it is very important for humans who are the main sources to be open and eager to learn and they should be promoted and provided the required environment. Turkey should give special attention to innovation, education, cultural and intellectual production in order to develop in knowledge society and to be able to have competitive advantage. Since states which make their citizens well-educated, specialized, creative, skilled to solve problems will be the ruler of the new era, Turkey needs to reduce the uneducated workforce. Innovation, science and education policies are critical for her progress. According to the Knowledge Economy Index pillars, Turkey should speed up the investments in ICT, increase R\&D expenditures, increase productivity in production by innovating, upgrade the level of education to have the required qualified human resources and should be directed to high-tech products in the production structure.

\section{References}

- $\quad$ Acar, 2000. "Bilgi Çağı ekonomisine Teorik Bir Yaklaşım", Dokuz Eylül Üniversitesi İ.İ.B.F Dergisi, 15, s $87-101$.

- Acar, 2000. Uluslararası Reel Ticaret, Teori, Politika, Dokuz Eylül Üniversitesi yayınları, İzmir.

- Arikan, 2008. Evaluating the dynamics of innovation in Turkey: The impact of innovation on business performance, Boğaziçi University, Business Administration, PhD Thesis, İstanbul.

- Asia Society, 2015. http://asiasociety.org/education/learning-world/what-pisa-and-why-does-it-matter

- Beig, vd, 2007. "Adoption a Proper Tool for E-Readiness Assessment in Developing Countries; Case Studies: Iran, Turkey and Malaysia", Journal of Knowledge Economy \& Knowledge Management Volume II Spring, s.54.

- CCirasun, 2011. "Enformasyon Toplumu ve Bilgi Çağında Türkiye'nin Gelişim Süreci", Marmara Üniversitesi, Sosyal Bilimler Enstitüsü, İktisat Politikası Bilim Dalı, Master Thesis, İstanbul.

- David ve Foray, 2002. "Economic Fundamentals of the Knowledge Society", Stanford University SIEPR Discussion Paper No.01-14.

- Düzgün 2008, Knowledge sector dimension of Turkish economy, Marmara University Social Sciences Institute, Economics, Master's thesis, İstanbul.

- European Comission, 2001. The Impact of the E-Economy on European Enterprises: Economic Analysis and Policy Implications, Brussels.

- European Commission, 2014. Innovation Union Scoreboard, http://ec.europa.eu/enterprise/policies/innovation/files/ius/ius-2014_en.pdf

- European Patent Office, 2015. http://www.epo.org/about-us/annual-reports-statistics/annualreport/2014/statistics/patent-applications.html

- Gür, 2001. Assessment of possible effective strategies in the transition process to a knowledge-based economy: The case of Turkey, Middle East Technical University Industrial Engineering Department, Master's Thesis, Ankara. 
- Iş1k 2012, The economic analysis of R\&D, innovation, patent and information technologies which influence the establishment of competitive advantage in knowledge economies: An application on Turkey's Economy, Atatürk University Social Sciences, Economics, PhD Thesis, Erzurum.

- Kara, 2005. Bilgi Ekonomisi'nin Olası Mikro Ekonomik Etkilerinin Teorik Analizi, http://oguzkara.com/Bilgi\%20Ekonomisi'nin\%20Olasi\%20Mikro\%20Ekonomik\%20Etkilerinin\%20Teorik \%20Analizi.pdf .

- Kaynak, 2011. "Avrupa Birliği Yolunda Bilim Ve Teknoloji Bağlamında Türkiye’nin Ab-27 Ülkeleri Karşısındaki Mevcut Durumu", Bilgi Ekonomisi ve Yönetimi Dergisi, Cilt: VI Sayı: II

- Meçik, 2013. "Türkiye İçin 2010-2012 Dönemi Karşılaştırmalı Bilgi Ekonomisi Analizi", Eskişehir Osmangazi Üniversitesi İktisadi ve İdari Bilimler Fakültesi Dergisi,2013, 8(2), s. 115-139.

- Memişoğlu, 2012. Knowledge-based economy and economic growth: Empirical analysis of BRICST Countries, Boğaziçi University Social Sciences International Trade Depaortment, Economics, Master's Thesis, İstanbul

- $\quad$ OECD, 1996. OECD, The Knowledge Based Economy, No. General Distribution OECD/GD(96)102, Paris.

- OECD, 2015. http://www.oecd.org/pisa/keyfindings/pisa-2012-results-overview.pdf

- Özcan, 2007. The case of organizations in Turkey from the perspective of knowledge economy, Afyon Kocatepe Üniversity, International Trade Department, Business Administration, Phd Thesis, Afyon

- Rondo, 2002. A Concise Economic History of the World (from paleolithic times to thepresent), Oxford Uni. Press, London.

- Tapscott, 1998. Dijital Ekonomi, Hora Matbaas1, İstanbul.

- Taşçı, 2007. "Teorik Çerçevesi ve Uygulama Örnekleriyle Dünyada ve Türkiye'deYazılım Endüstrisi”, Devlet Planlama Teşkilatı Müsteşarlığı, Planlama Uzmanlığı Tezi (yayımlanmamış eser), Ankara.

- T.C Başbakanlık Türkiye Yatırım Destek ve Tanıtım Ajansı, 2014, http://www.invest.gov.tr/trtr/sectors/Pages/ICT.aspx .

- $\quad$ Toffler, 1984. The Third Wave, Bantam Books, New York.

- TPE, 2015. http://www.tpe.gov.tr/TurkPatentEnstitusu/statistics/

- UNESCO, 2015. http://www.uis.unesco.org/Education/Documents/literacy-statistics-trends-1985-2015.pdf

- World Bank, 2003. Lifelong Learning for a Global Knowledge Economy, Washington, DC

- World Bank, 2004. "Turkey Knowledge Economy Assessment Study", http://wwwwds.worldbank.org/external/default/WDSContentServer/WDSP/IB/2007/04/06/000310607_2007040611350 1/Rendered/PDF/393650TR0Knowledge0economy01PUBLIC1.pdf .

- World Bank, 2010. Knowledge Assessment Methodology, http://www.worldbank.org/kam .

- World Bank, 2015. http://data.worldbank.org/indicator/SE.SEC.NENR/countries

- YASED International Investors Association,2014, http://www.yased.org.tr/webportal/Turkish/Yayinlar/Pages/YASED2023HedefleriYolundaBIT.aspx 